International Journal of Management Science and Business Administration

Volume 3, Issue 4, May 2017, Pages 20-24

DOI: 10.18775/ijmsba.1849-5664-5419.2014.34.1002

URL: http://dx.doi.org/10.18775/ijmsba.1849-5664-5419.2014.34.1002

\title{
The Politics Of The Environment: Power Contestation Over Ecological Space In Purbalingga
}

\author{
${ }^{1}$ Andi Ali Said Akbar, ${ }^{2}$ Ahmad Sabiq, Oktaviani Catur Pratiwi \\ ${ }^{1,2,3}$ Faculty of Social and Political Sciences, Universitas Jenderal Soedirman
}

\begin{abstract}
This study aims to analyze the institutional capacity of local governments and community-based ecopopulism in the face of disasters caused by industrial waste. It is significantly because of frequent pollution in the village of Penambongan, Kandanggampang and Purbayasa, Purbalingga Regency. Pollution mainly came from waste disposal factories which caused not only material losses but also environmental damage. The study used a qualitative research method with a case study approach. The findings are as follows: the institutional capacity of community and government were still weak in resolving the problem which was so prone to lead to conflict and severe environmental damage as well. On the one hand, although it is often harmed by industrial waste, the capacity of community in the fight for ecological justice has not been sufficient. On the other hand, the capacity of government in developing environmentally-friendly economic development in Purbalingga was still low. Institutionally, the roles of the Environment Agency looked like deliberately torpor. As a result, in almost all disputes between communities and companies associated with pollution, the companies could easily win the contestation of power. To this day companies polluting the environment seem untouched, and still continue to run
\end{abstract}

Keywords: Environmental Pollution, Power Contestation, Institutional Capacity

\section{Introduction}

The Regency of Purbalingga as an investment-friendly region was characterized by high level of investment. In this regency, there are 158 factories that produce a variety of industrial products, open and absorb employment and increase local revenue. Behind all these positive things, however, there is a negative side regarding the threat of industrial disaster. Throughout the end of 2014 up to mid-2015 several villages in Purbalingga were troubled by the high incidence of industrial waste pollution

In September 2014 the residents of Penambongan Village suffered because thousands of fish in their ponds died suddenly. Allegedly, the death of the fish was due to pollution from factory waste. The allegations were strong enough and grounded, as companies disposed their waste carelessly into Keramean River flowing in the region. Losses due to this contamination expected to reach 20 million rupiahs (Harian Banyumas, 24/09/2014). Similar incidents were also confirmed by the residents of Kandanggampang and Purbayasa Village. They suspected that the fish deaths were caused by water flowing in their ponds from the river which had been polluted by the waste of wig factories. Moreover, their fish pond smelt like the smell of wig factories' sewage.

The allegations regarding water pollution finally revealed. Laboratory testing of environmental agency (BLH) of Purbalingga Regency found a number of chemicals from PT. Boyang Industrial that was above the quality standard (Radar Banyumas, 28/03/2014). Local governments seemed slow to address the problem. This could be seen from the length of time and the process must be taken by the people to ascertain the full study findings and proposed solutions. The pollution took place in September 2014 while the laboratory testing conducted in March 2015. BLH indicated that more than 20 plants, including PT Boyang Industrial, were still stubborn and did not treat waste properly. This was evident from the monitoring activities conducted periodically. So far, if the plants remain stubborn, BLH will instruct investigators to obtain laboratory evidence and will be firm in cooperation with the police to follow up on it (Radar 
Banyumas, 06/04/2015). During that time people continue to struggle for justice. As a result, the disputes, threats, and vulnerabilities of conflict between residents and the company cannot be avoided.

This research is important in order to observe the capacity of local government and the capacity of rural communities' movement against the environmental pollution after the extent of industrialization in Purbalingga.

\section{Research Method}

The method used in this study is a qualitative research method. As stated by Bogdan and Taylor qualitative research can be defined as a research procedure that produces descriptive data in the form of words both written and spoken of people and their behaviors that can be observed. According to them, this approach is directed holistically (Moleong, 2007). The use of qualitative research method aimed to obtain more complete and profound data. Because this method is used to examine the condition of natural objects, where the researcher is a key instrument, and the findings have more emphasis on meaning rather than generalization (Sugiyono, 2008). The approach used in this study is a case study, a type of approach based on a case that is done in the intensive, in-depth, detailed and comprehensive way (Faisal 1999).

\section{Literature Review}

\subsection{Institutional Organization Theory}

An organization is not a set of components that is lifeless because therein consists of individuals or groups who are not static. Each pass and offer many ideas or perspectives. Although the mechanism of the organization cannot be avoided, the nature of humanity is not interchangeable with engine components. Humans create, maintain, modify or terminate the organization through his behavior that is constantly changing. Organizations exist only through those who struggle in interaction (Pace and Faules, 2006).

Similarly, Thelen and Steinmo (1992) see the leader as the agency referring to the ability of an actor in influencing the social world, changing the rules and distributing resources. However, the degree varies among actors and the type of social structure. Agency is structured socially. In principle, institution contains elements of rules, norms, values, goals and the actor's behavior.

\subsection{Environmental Theory of Ecopopulism}

Ecology today has evolved into a "star" among the branches of science which have only considered being a supporting study. Ecological principles can explain and inspire us in finding a way to achieve a better life. Ecology is the study of the influence of environmental factors on living bodies, or science that attempts to study the relationship between the living and the environment where they live, what her life, and why they were there. Ecology has reached an advanced stage of studying the structure and function of ecosystems where humans are part of nature (Irwan, 2005).

According to Lay (2007) environment is one of the few issues such as democracy, rights, human rights, poverty, security and issues around children and women that have gained strength in recent years and proved robust in integrating the nation and people of different races into a single unified and more constructive global relation. Almost every nation put the environment as a common language in the chain of politics that connects a nation with the global community. The environment has become the ideology of humanism among nations, communities, and individuals of any race, ideology, cultural and economic levels.

\subsection{Power contestation Over Ecological Space}

Economic and ecological power contestations are increasingly visible and able to spread and even lead to structured conflicts. Today we are witnessing the structured conflicts competing for spatial life and life between actors at national and regional level.

This contradiction has long been explored by van Ufford and Giri (2004). They stated that the planning of a development agenda is an activity that requires the involvement of a moral dimension and empirical dimension that is comprehensive. Learning to combine both dimensions is an important effort because so many recipes that offer a method to do that until now have failed and still reap the conflict. Development should contain aspects of hope, 
political aspects, and aspects of critical reflection. But in practice, in many places, these aspects were run separately. At the local level ranging from Regency to village, ecological destruction began to spread. Since regional autonomy was punctuated by the spirit of political autonomy and acceleration of welfare, many political elites pursue the progress of the region.

Decentralization facilitates local governments to formulate accelerated economic policies by chasing high rates of local revenue. The most effective formula is to bring investors and start industrialization. The vision of agropolitan area later turned into a metropolitan vision. Development of the village turned into the myth of the big city. Regional autonomy turned into regional "automoney."

Annexation of fertile land for the provision of food by sectors of industrial production, housing and services also showed collisions of interest (Keraf, 1998).[12] In Law No. 17 of 2007 on the National Long-Term Development Plan for 2005-2025 it was argued that this crisis occurs at least because: (1) development of a given region are often carried out without following the layout plan; (2) does not consider the sustainability and environmental carrying capacity; and (3) does not pay attention to the vulnerability of the region to natural disasters. The appendix of this law highlighted that the desire for short-term economic gains by exploiting the natural resources in the exaggerated and irresponsible way have sacrificed the quality and quantity of natural resources and the environment, and increase the risk of casualties due to natural disasters (mainly due to human activities that harm the environment)

\section{Result and discussion}

\subsection{Industrialization in Purbalingga}

Figure 1 shows the dynamic movement for share price starting from January 2010 until October 2016. The initial stock Through Regent Decree No. 27 of 2002 investment development and financial institutions were considered very important in the economic development of the region. The development of investment activity by itself was believed to increase the production activities that have an impact on increasing production which means an increase in the GDP, which also means an increase in per capita income. The policy resulted in the need for labor and the increasing number of foreign companies, who invest in Purbalingga. This regency was known as the biggest producer of hair and eyelashes in the world after Guangzhou, China, which are exported to America, Europe, and some countries in Asia. Until now in Purbalingga there are at least 18 foreign investment companies engaged in manufacturing hair and eyelashes (http://www.promojateng-pemprovjateng.com, 14/11/2016). [13]

In 2009 Purbalingga was re-elected as the most pro-investment areas in Central Java, after winning the same award in 2004. Purbalingga managed to outperform four other Regencies in Central Java that fell within the top five by winning score of 3.888. Four Regencies which ranked two to five respectively along with their score were Banyumas $(3,877)$, Tegal (3538), Kudus (3528), and Wonosobo (3485) (Banyumasnews.com, 24/07/2009). [14]

\subsection{Dealing with the Waste}

This study yielded interesting findings about the efforts of the villagers to recognize the symptoms of pollution in the river. This knowledge is called the capacity of disaster mitigation. The experience in dealing with this disaster will form a pattern of response of villagers to understand and anticipate the pollution. What's interesting about this finding is that people have understood the patterns of vulnerability caused by the waste. If the pollution occurred in the rainy season, the fish farmers were not worried because the river was flowing profusely. The waste would be swept quickly through the area of fish farming. Automatically, fish ponds were not polluted.

However, entering the dry season, people would feel anxious. That was when the water flow reduced, the stream weakened, and puddles began to form. At the same time, the activity of industries continued regardless of the seasons. Both in the dry or wet season, the waste was dumped carelessly into the river on a massive scale. According to the residents, in the dry season when the river was polluted water then turned black, foamy and smelly. The color of contaminated fish would change, even up to the internal organs. Residents did not dare to consume the fish, let alone to sell them. 
To save their fish pond, people were willing to oversee the color change of the river. Residents then took turns to patrol, to check whether the river was polluted. This shows how weak their capacity of disaster mitigation. Industrial waste disaster was merely responded through tactical anticipation to reduce losses.

Residents reported that until now, people are often disadvantaged by the waste. If the loss was small, the factory and the local government did not pay any attention. If the loss were great, they would still ignore it unless there were protests from the public. Recent protests have not been significant because it cannot touch the power of policy-makers. Their movement was still partial and did not involve a well-organized movement.

\subsection{Government Ambivalence}

How is the capacity of local governments to manage ecological issues? We cannot deny that the existence of these factories is important to address unemployment and poverty as well as a source of local revenues (PAD). However, this vision does not take into account the fate of farmers. Factories produce goods and provide wages to workers but on the other hand eliminate the sources of income of farmers affected by the waste industry.

Data from BLH which institutionally deal with environmental management shows that of the 158 factories in Purbalingga, only one factory categorized as "BLUE" which means to have integrity, professionalism and excellent infrastructure to manage waste and preserve the surrounding ecology. The rest is categorized as "RED" which means often violate the ecological regulations, does not have the integrity, professionalism, and waste treatment facilities and protecting the surrounding environment. This predicate has been attached for a long time and has not changed.

The local governments itself in this case the Regent and the Parliament has not yet formulated a fixed rule in the form of regulations of the Environment. So far they've only talked about the draft related regulations and have not looked seriously to make it happen. In addition, the working capacity of BLH was still weak. For example, the agency has only one chemical analyst. This is the guy who took care of everything from administrative work to examine the work in the laboratory and surveillance installation of sewage treatment plant. The agency has long had limited personnel, authority, budget, and facilities.

Moreover, the authority of environmental management operationally was scattered, in several agencies. This is the main problem of bureaucracy that tends to expand authority rather than competence that resulted in overlapping programs. For example, environmental management is handled not only by BLH but also by the office of health, social, agriculture and cleaning, and gardening. The spread of authority like this just makes incompetent bureaucracy, wasteful spending, and conflict of interest.

BLH yet did not have an accredited chemical laboratory. Therefore its laboratory findings cannot be used as evidence of pollution by the standard of law in Indonesia. If people come to complain, carrying evidence of contamination and then the laboratory results of BLH prove the pollution, it still cannot be used as evidence in court.

Regency that has hundreds of factories should strengthen the capacity of its BLH. This is an example of the lack of seriousness of the local government in protecting the ecology of the region. Local Government is more interested in the aspect of increasing employment and revenue at the expense of the ecology as well as farmers who depend on ecological sustainability. The bad portraits of environmental management and waste management industry made the Ministry of Environment put Purbalingga as one of the main targets of the environmental monitoring program. They hoped this program can improve the environmental awakening and improving waste treatment facilities in the factories.

The weak capacity of the government and community on environmental protection makes the position of the factories in the contestation of power at the local level to be strong. Therefore, in almost all conflicts between communities and companies related to pollution, companies can easily win the case. Therefore until now, companies polluting environment can still continue to operate and was not affected by the cases of environmental pollution they have committed. 


\section{Conclusion}

As pro-investment regency, Purbalingga is a friendly place for large factories to operate. Unfortunately, almost all the factories are often in violation of ecology. There was only one factory that met environmental protection criteria. This is evident from the frequent pollution in some areas of the regency. Among the pollution, one thing was very disturbing their livelihood, namely the disposal of industrial waste into the river. This has led to huge losses of the fish farmers whose fish pond filled with water of the river.

Despite the frequent loss due to industrial waste, the capacity of the community in the fight for ecological justice has not been good enough. Ironically, the government also did not comprehensively regulate and control these environmental violations which can lead to conflict between the company and affected communities. Thus, the institutional capacity of government and community in the political scene of Purbalingga were still weak. Power contestation over ecological space in Purbalingga was still dominated by the factories.

These findings should be a reference for designing ecological protection policies. The government should make ecology as the basis of environmental policy, spatial arrangement and pioneering efforts of environment-friendly industry.

\section{Acknowledgement}

This work was made possible through the research grant obtained from Ministry of Research, Technology and Higher Education, Republic of Indonesia under the Riset Institusi Unsoed Scheme 2016.

\section{References}

- BLH Akan Gandeng Polisi, Radar Banyumas, 6 April 2015

- Faisal, S., 1999, Format-Format Penelitian Sosial, Rajawali Pers, Jakarta

- Irwan, Z. D., 2005, Tantangan Lingkungan dan Lansekap Hutan Kota, Bumi Aksara, Jakarta

- Keraf, A.S., 1998, Etika Bisnis. Tuntutan dan Relevansinya, Kanisius Yogyakarta

- Lay, C., 2007, Introductory Paper, presented in Seminar"Pembangunan Daerah Yang Berwawasan Hukum Lingkungan', Yogyakarta

- Moleong, L.J., 2007, Metodologi Penelitian Kualitatif Remaja Rosdakarya, Bandung

- Pace, R.W. and Faules, D.F., 2006, Komunikasi Organisasi: Strategi Meningkatkan Kinerja Perusahaan, Rosda Karya, Bandung

- Purbalingga Peringkat I Kabupaten Pro- Investasi 2009, Banyumasnews.com, 24.

- Rambut dan Bulu Mata Palsu, promojateng-pemprovjateng.com, 14 November

- Ribuan Ekor Ikan Mati Mendadak: Diduga Tercemar Limbah Pabrik Rambut,

- Sugiyono,2008, Metode Penelitian Kualitatif dan R\&D, CV Alfabeta, Bandung

- Thelen, K. and Steinmo, S., 1992, Historical Institutionalism in Comparative Politics,

- Van Ufford, P.Q., and Giri, A. K., (ed), "Kritik Moral Pembangunan". Kanisius, Yogyakarta. 2004

- Warga Resah, Ribuan Ikan Mati Mendadak; Diduga Tercemar Limbah Pabrik, 